\title{
UPAYA PENINGKATAN KEMAMPUAN MEMORI DAN PRESTASI BELAJAR SISWA SMA DENGAN MENGGUNAKAN MODEL PEMBELAJARAN TEAM ASSISTED INDIVIDUALIZATION DILENGKAPI MEDIA LKS BERBASIS DRILL AND PRACTICE PADA MATERI HIDROKARBON
}

\author{
Yuni Hidayani, Endang Susilowati ${ }^{\star}$, dan Nurma Yunita Indriyanti \\ Program Studi Pendidikan Kimia, FKIP, Universitas Sebelas Maret, Surakarta, Indonesia \\ *Keperluan Korespondensi, telp: 081548553791, email: endwati@yahoo.co.id
}

\begin{abstract}
ABSTRAK
Penelitian ini bertujuan untuk meningkatkan kemampuan memori dan prestasi belajar siswa kelas X SMA N Kebakkramat pada materi hidrokarbon dengan model pembelajaran Team Assisted Individualization (TAI) dilengkapi LKS berbasis drill and practice. Penelitian ini merupakan Penelitian Tindakan Kelas (PTK) yang dilakukan dalam dua siklus. Setiap siklusnya terdapat empat tahapan, yaitu perencanaan, pelaksanaan, observasi, dan refleksi. Subjek penelitian adalah siswa kelas X-2 SMA Negeri Kebakkramat tahun pelajaran 2016/2017. Data diperoleh melalui observasi, wawancara, kajian dokumen, angket dan tes. Teknik analisis data yang digunakan dalam penelitian ini adalah deskriptif kualitatif. Hasil penelitian menunjukkan bahwa penerapan model pembelajaran TAI dilengkapi dengan LKS berbasis drill and practice dapat meningkatkan kemampuan memori dan prestasi belajar siswa kelas X-2 SMA Negeri Kebakkramat pada materi hidrokarbon tahun pelajaran 2016/2017. Peningkatan kemampuan memori siswa pada materi hidrokarbon dapat dilihat dari kenaikan presentase siswa sebesar $38,89 \%$ pada siklus I dan meningkat menjadi $63,89 \%$ pada siklus II. Prestasi belajar siswa pada materi hidrokarbon dapat dilihat pada aspek kognitif dan afektif. Berdasarkan hasil tes siklus I ketercapaian aspek kognitif sebesar $44,44 \%$ dan meningkat menjadi $75 \%$ pada siklus II. Ketercapaian aspek afektif siswa sebesar $72,22 \%$ pada siklus I dan meningkat menjadi $89,11 \%$ pada siklus II.
\end{abstract}

Kata Kunci: Penelitian Tindakan Kelas, TAI, LKS drill and practice, Kemampuan Memori, Prestasi Belajar, Hidrokarbon

\section{PENDAHULUAN}

Kemajuan suatu bangsa sangat dipengaruhi oleh kualitas Sumber Daya Manusia (SDM) yang dimiliki bangsa tersebut. Bangsa yang tidak ingin tertinggal harus mengikuti perkembangan ilmu pengetahuan dan teknologi dari waktu ke waktu untuk menciptakan SDM yang berkualitas. Selain itu, pemerintah perlu melakukan peningkatan mutu pendidikan untuk meningkatkan kualitas SDM, karena pendidikan memiliki pengaruh yang besar dalam menentukan masa depan dan kelangsungan hidup suatu bangsa. Salah satu upaya yang dilakukan pemerintah Indonesia dalam mem- perbaiki pendidikan adalah perbaikan kurikulum [1].

Indonesia sudah beberapa kali mengubah kurikulum pendidikan yang bertujuan untuk membuat pendidikan di Indonesia semakin baik ke depannya. Kurikulum terbaru yang berlaku di Indonesia adalah Kurikulum 2013, namun masih ada beberapa sekolah yang belum menerapkan kurikulum ini dengan berbagai alasan dan masih menggunakan kurikulum sebelumnya yaitu Kurikulum Tingkat Satuan Pendidikan (KTSP).

SMA Negeri Kebakkramat merupakan salah satu sekolah yang masih menerapkan Kurikulum Tingkat 
Satuan Pendidikan (KTSP). Dalam KTSP guru diberikan kesempatan untuk mengembangkan indikator pembelajaran dan pemilihan materi yang disesuaikan dengan kebutuhan sekolah masing-masing [1]. Selain itu, penerapan KTSP ditekankan pada pendekatan proses dan pendalaman materi melalui proses bukan pemaksaan pencapaian materi. Dengan demikian dalam pembelajaran harus melibatkan aktivitas peserta didik sedangkan guru hanya berperan sebagai mediator dan fasilitator dalam mencapai tujuan pembelajaran.

Kondisi real pada saat pembelajaran yang teramati melalui observasi menunjukkan bahwa pembelajaran masih berpusat pada guru (teacher centered) karena metode yang digunakan adalah metode ceramah dan pemberian tugas. Guru hanya memberikan contoh soal dan memberikan tugas di akhir pembelajaran, sehingga siswa merasa takut dan canggung untuk bertanya kepada guru apabila ada materi yang belum paham. Hal tersebut menyebabkan siswa menjadi pasif dan merasa jenuh dalam mengikuti kegiatan belajar mengajar sehingga materi yang dipelajari tidak diserap secara sempurna. Masalah utama dalam pembelajaran di sekolah adalah masih rendahnya daya serap siswa yang akan berdampak pada rendahnya hasil belajar siswa yang disebabkan oleh pembelajaran yang masih besifat konvensional [2].

Berdasarkan hasil wawancara dengan guru mata pelajaran kimia kelas $X$ pada tanggal 3 Januari 2017 di SMA Negeri Kebakkramat, siswa kelas X pada semester genap memiliki nilai rata-rata dan ketuntasan relatif lebih rendah pada materi hidrokarbon karena pada materi hidrokarbon lebih banyak menggunakan kemampuan memori. Siswa cenderung malas untuk mem-pelajari materi-materi yang sebagian besar berisi teori dan konsep kimia. Oleh sebab itu, pada materi hidrokarbon siswa cenderung mengalami kesulitan dalam memberi nama senyawa hidrokarbon, menuliskan reaksi sederhana pada senyawa hidrokarbon, dan menentukan isomer.
Persentase ketuntasan nilai ulangan harian siswa kelas $X$ pada materi hidrokarbon tahun pelajaran 2015/2016 adalah 30,97\%. Materi hidrokarbon banyak mengandung konsep dan teori serta materi ini banyak menggunakan istilah-istilah dalam bahasa Yunani (tata nama senyawa hidrokarbon) dan bahasa simbolik (rumus kimia senyawa hidrokarbon). Materi hidrokarbon meliputi kekhasan atom karbon, penggolongan hidrokarbon, dan keisomeran.

Salah satu upaya untuk meningkatkan kemampuan memori dan prestasi belajar siswa X SMA Negeri Kebakkramat digunakan model pembelajaran Team Assisted Individualization (TAI). Model pembelajaran TAI mengkombinasikan keunggulan pembelajaran kooperatif dan pembelajaran individual [3]. Model pembelajaran TAI adalah model pembelajaran yang membentuk kelompok kecil yang heterogen dengan latar belakang cara berpikir siswa yang berbeda sehingga dapat saling membantu siswa lain yang membutuhkan bantuan [4]. Dengan demikian, dalam penerapan model pembelajaran TAI terjadi bimbingan antar teman, dimana siswa yang pandai akan membantu siswa yang kurang pandai.

Sintaks TAl terdiri dari 7 tahap sebagai berikut, (1) pemberian tugas kepada siswa untuk mempelajari materi pelajaran secara individual (student creative), (2) menentukan asisten bagi tiap kelompok (placement test), (3) mengorganisasikan ke dalam kelompok kooperatif. (team), (4) diskusi dalam kelompok (team study), menyimpulkan materi (whole class), (6) pemberian kuis secara individual (fact test), (7) skor kelompok dan pengakuan kelompok (Team scores and team recognition) [5].

Model pembelajaran yang diterapkan akan berhasil apabila ditunjang dengan media pembelajaran yang baik. Media ini bertujuan untuk membantu siswa dalam mengembangkan konsep, melatih siswa untuk menemukan dan mengembangkan 
proses belajar mengajar, sebagai alat bantu guru dan siswa dalam melaksanakan proses belajar mengajar, membantu siswa untuk menambah informasi tentang konsep, dan membantu siswa memperoleh catatan materi yang dipelajari dalam melakukan kegiatan pembelajaran. Media yang dapat digunakan untuk membantu siswa belajar mandiri dan bisa meningkatkan kemampuan siswa dalam menganalisis soal adalah LKS (Lembar Kerja Siswa) yang berbasis drill and practice.

Untuk mendukung model pembelajaran dan media dalam penelitian ini, digunakan metode drill and practice sebagai dasar penyusunan materi dan soal pada LKS. Metode latihan atau drill and practice adalah teknik pembelajaran berupa latihan dan praktik yang diberikan secara berulangulang untuk mengasah keterampilan dan ketangkasan siswa, sehingga pembelajaran tidak berpusat pada guru dan siswa akan lebih paham dengan apa yang telah dipelajari [6]. Penggunaan metode drill and practice pada dasar penyusunan LKS pada penelitian ini untuk mengarahkan dan menuntun pemahaman konsep materi hidrokarbon khususnya pada sub bahasan keisomeran pada siswa, karena metode ini menerapkan latihan-latiahan yang secara berulang-ulang, sehingga dapat meningkatkan kemampuan memori dan prestasi belajar siswa. Oleh sebab itu, isi dari LKS akan terstruktur sesuai dengan sintaks drill and practice.

Penerapan model pembelajaran TAI dilengkapi dengan LKS berbasis drill and practice diprediksi dapat meningkatkan kemampuan memori dan prestasi belajar siswa. Hal ini didukung dengan hasil penelitian model pembelajaran TAI dapat meningkatkan kemampuan memori dan prestasi belajar siswa pada materi hidrokarbon [7]. Selain itu juga didukung dengan hasil penelitian bahwa penggunaan LKS dapat meningkatkan keberhasilan siswa dalam mempelajari suatu materi yang akan berdampak pada peningkatan prestasi belajar [8].

$$
\text { Berdasarkan latar belakang }
$$
masalah di kelas $X$ SMA Negeri
Kebakkramat, peneliti menyimpulkan perlu adanya Penelitian Tindakan Kelas (PTK) yang dimaksudkan untuk meningkatkan kemampuan memori dan prestasi belajar siswa melalui penerapan model pembelajaran TAI dilengkapi dengan LKS berbasis drill and practice.

\section{METODE PENELITIAN}

Penelitian yang dilakukan merupakan penelitian tindakan kelas (PTK). Dalam melaksanakan penelitian tindakan kelas dibutuhkan empat tahapan yaitu 1) perencanaan (planning), 2) tindakan (acting), 3) pengamatan (observing), 4) refleksi (reflecting), dari rangkaian tahapan tersebut akan terbentuk menjadi sebuah siklus [9]. Subjek pada penelitian ini adalah siswa kelas X-2 semester genap SMA Negeri Kebakkkramat tahun pelajaran 2016/2017 dengan jumlah 36 siswa yang terdiri dari 10 siswa laki-laki dan 26 siswa perempuan.

Teknik pengumpulan data yang digunakan dalam penelitian ini meliputi tes, observasi, wawancara, kajian dokumen dan angket. Analisis data dilakukan menggunakan teknik kualitatif. Teknik analisis kualitatif dilakukan dalam tiga komponen yaitu, reduksi data, penyajian data dan penarikan kesimpulan dan verifikasi [10].

Instrumen penilaian pada aspek kognitif yaitu tes objektif. Soal tes kemampuan memori yang digunakan adalah dari Departemen Psikometri Fakultas Psikologi Universitas Gadjah Mada yang sudah dimodifikasi [11]. Soal tes kemampuan memori sebanyak 30 butir soal. Soal-soal tersebut berisikan daftar pasangan kata senyawa hidrokarbon yang harus diingat siswa. Instrumen yang digunakan untuk mengukur aspek afektif yaitu berupa angket penilaian diri.

\section{HASIL DAN PEMBAHASAN}

Pada awal tindakan dilakukan tahap wawancara, kajian dokumentasi dan observasi untuk mengetahui kondisi awal siswa. Data hasil wawancara dengan guru menunjukkan bahwa siswa 
kelas X SMA Negeri Kebakkramat mengalami kesulitan pada materi yang lebih banyak menggunakan kemampuan memori, dikarenakan siswa cenderung malas untuk mempelajari materi-materi yang berisi teori dan konsep kimia. Hasil kajian dokumentasi diperoleh bahwa ketuntasan nilai siswa pada materi hidrokarbon pada tahun pelajaran 2015/2016 sebesar 30,97\%. Sedangkan dari hasil observasi pembelajaran di kelas masih berpusat pada guru (teacher centered). Sehingga perlu dilakukan tindakan untuk menangani permasalah tersebut dengan menggunakan model pembelajaran TAl dilengkapi dengan LKS berbasis drill and practice.

\section{Siklus I}

\section{a. Perencanaan Tindakan}

Pada tahap perencanaan, peneliti dan guru melakukan kajian terhadap silabus mata pelajaran kimia. Silabus berasal dari guru dan dikembangkan oleh peneliti. Berdasarkan silabus ini peneliti membuat rencana pelaksanaan pembelajaran (RPP). Selanjutnya adalah penyusunan instrumen kemampuan memori, aspek kognitif dan aspek afektif.

Pada siklus I terdiri dari 3 pertemuan, setiap pertemuan menggunakan model pembelajaran TAI dilengkapi dengan LKS berbasis drill and practice.

\section{b. Pelaksanaan Tindakan}

Pelaksanaan tindakan pada siklus I berupa serangkaian kegiatan pembelajaran di kelas X-2 SMA Negeri Kebakkramat menggunakan model pembelajaran TAI dilengkapi dengan LKS berbasis drill and practice yang berlangsung sesuai sintaks yang telah tersusun dalam rencana pelaksanaan pembelajaran. Siklus I terdiri dari 2 kali pertemuan penyampaian materi dan 1 kali pertemuan untuk kegiatan evaluasi, kegiatan evaluasi berupa pemberian soal tes kognitif, angket afektif dan tes kemampuan memori. Alokasi waktu pertemuan pertama adalah $2 \times 45$ menit, pertemuan kedua adalah $1 \times 45$ menit dan pertemuan ketiga adalah $2 \times 45$ menit.
Pada pertemuan pertama diawali dengan mengkondisikan kelas, absensi siswa, memberikan apersepsi, orientasi dan motivasi. Pada pertemuan pertama guru membahas tentang indikator kompetensi yang pertama yaitu pengertian isomer, dan indikator kompetensi yang kedua yatu menentukan isomer struktur (kerangka dan posisi) pada senyawa hidokarbon. Pada kegiatan inti, guru membagikan LKS berbasis drill and practice kepada setiap siswa pada pertemuan pertama di siklus I. Kemudian guru memberikan tugas kepada siswa untuk mempelajari materi pelajaran yang sudah disiapkan oleh guru secara individual. Siswa dibagi menjadi 9 kelompok yang terdiri dari 4 siswa dalam setiap kelompok. Pemilihan kelompok dilakukan secara heterogen berdasarkan atas nilai ulangan kimia pada materi sebelumnya, kemudian diambil sembilan siswa dengan nilai tertinggi yang bertugas sebagai asisten disetiap kelompok. Selanjutnya, siswa dalam kelompok dipersilahkan berdiskusi untuk menjawab soal-soal dalam LKS berbasis drill and practice. Hal ini diharapkan akan melatih siswa untuk dapat menyelesaikan masalah dengan mengandalkan pemahaman dan kemampuan memori, kemudian siswa juga dilatih untuk bekerjasama dalam menyelesaikan suatu masalah dengan berbagai pemahaman dan memori individual siswa yang berbeda.

Setelah siswa berdiskusi, kemudian perwakilan kelompok mempresentasikan hasil diskusi. Guru memberikan umpan balik berupa pujian kepada kelompok yang mempresentasikan hasil diskusi dengan benar. Kemudian terhadap kelompok yang mempresentasikan hasil diskusi yang kurang tepat, guru memberikan kesempatan kepada kelompok lain untuk memberikan tanggapan atau jawaban yang lebih tepat. Guru memberikan penghargaan pada kelompok bedasarkan perolehan nilai kelompok paling tinggi. Pada kegiatan akhir, siswa dengan bimbingan guru menyimpulkan hasil pembelajaran. Kemudian guru memberikan soal kepada siswa yang berkaitan dengan materi isomer struktur 
senyawa hidrokarbon dan dikerjakan siswa secara individu.

Pada pertemuan kedua tidak jauh beda dengan pertemuan pertama namun pada pertemuan ini guru membahas tentang indikator kompetensi yang ketiga yaitu menentukan isomer geometri (cistrans) pada senyawa hidrokarbon. Pada pertemuan kedua keaktifan siswa dalam proses pembelajaran semakin meningkat. Hal ini dapat dilihat dari keaktifan siswa dalam menyampaikan pendapat saat berdiskusi sudah mulai terlihat. Siswa juga sudah terlihat tidak canggung saat berdiskusi dengan kelompoknya. Pada kegiatan diskusi, sudah tidak ada siswa yang bertanya mengenai jawaban soalsoal diskusi pada teman kelompok yang lain. Setiap kelompok tampak lebih serius dalam mengerjakan soal-soal tersebut. Pada saat presentasi, anggotaanggota kelompok mulai berani mempresentasikan jawaban mereka di depan kelas.

\section{c. Observasi Tindakan}

Pada pertemuan pertama keseluruhan siswa sudah mengikuti pembelajaran dengan baik, meskipun masih ada 2-3 siswa yang mengobrol dengan teman waktu pembelajaran berlangsung. Siswa tampak tertarik dan antusias ketika guru membagikan LKS berbasis drill and practice sebagai media pembelajaran, karena media ini berbeda dengan buku pegangan siswa yang berisi banyak teori , dimana media LKS ini berisikan ringkasan materi dan soalsoal yang disajikan secara runtut sesuai dengan materi yang dipelajari sehingga lebih menarik dan membuat siswa lebih mudah dalam memahami materi.

Antusias siswa untuk aktif mengikuti pembelajaran juga masih kurang karena ada 2 siswa yang mengerjakan soal latihan tentang isomer struktur di papan tulis, ada 5 siswa yang bertanya mengenai materi yang dipelajari, misalnya apakah perbedaan isomer posisi dengan isomer kerangka. Ada 2 siswa yang menjawab pertanyaan guru tanpa ditunjuk ketika guru menanyakan tentang isomer struktur pada senyawa hidrokarbon. Namun pada pertemuan kedua sudah ada 3 siswa yang maju untuk mengerjakan soal latihan tentang isomer geometri di papan tulis, ada 7 siswa yang bertanya mengenai materi yang dipelajari, misalnya mengapa isomer geometri hanya terjadi pada senyawa alkena saja. Ada 5 siswa yang menjawab pertanyaan guru tanpa ditunjuk, misalnya ketika guru menanyakan tentang ada tidaknya isomer geometri pada suatu senyawa hidrokarbon. Hal ini menunjukkan antusias siswa mulai meningkat.

Aspek proses yang dinilai pada penelitian ini adalah kemampuan memori siswa pada materi hidrokarbon. Menurut Walgito kemampuan memori merupakan kemampuan untuk memasukkan (learning), menyimpan (retention), dan menimbulkan kembali (remembering) hal-hal yang telah lampau [12]. Penilaian kemampuan memori dilakukan pada akhir siklus I dan hasilnya dikelompokkan menjadi 3 yaitu kemampuan memori tinggi (T), kemampuan memori sedang (S), dan kemampuan memori rendah $(\mathrm{R})$ [13].

Hasil penilaian terhadap kemampuan memori siswa pada awal siklus dan siklus I dinyatakan dalam Tabel 1.

Tabel 1. Hasil Penilaian Kemampuan Memori Awal Siklus dan Siklus I

\begin{tabular}{ccccc}
\hline \multirow{2}{*}{ No } & Kemampuan & \multicolumn{4}{c}{ Jumlah Siswa (Orang) } \\
\cline { 3 - 5 } & Memori & $\mathrm{T}$ & $\mathrm{S}$ & $\mathrm{R}$ \\
\hline 1. & Awal & 7 & 8 & 21 \\
2. & Siklus I & 14 & 14 & 8 \\
\hline
\end{tabular}

Hasil analisis tes kemampuan memori menunjukkan bahwa pada akhir siklus I siswa dengan kategori kemampuan memori tinggi sebanyak 14 siswa atau 38,89\%, siswa yang masuk dalam kategori kemampuan memori sedang sebanyak 14 siswa atau $38,89 \%$, dan siswa yang masuk kategori kemampuan memori rendah sebanyak 8 siswa atau 22,22\%. Hasil ini menunjukkan peningkatan dibandingkan hasil tes kemampuan memori di awal siklus, dimana hasil tes kemampuan memori awal sebanyak 58,35\% siswa masuk dalam kategori rendah, 22,22\% siswa masuk dalam kategori sedang dan 
19,44\% siswa masuk dalam kategori tinggi. Hasil tes kemampuan memori pada siklus I belum mencapai target yang ditetapkan, yaitu sebesar $60 \%$ siswa berkemampuan memori tinggi sehingga dilanjutkan pada siklus II.

Hasil tes aspek kognitif pada siklus I dapat dilihat pada Tabel 2

Tabel 2. Hasil Tes Aspek Kognitif Siklus I

\begin{tabular}{lcc}
\hline \multirow{2}{*}{ Aspek } & \multicolumn{2}{c}{ Jumlah siswa } \\
\cline { 2 - 3 } & Tuntas & Belum Tuntas \\
\hline Kognitif & 16 & 20 \\
\hline
\end{tabular}

Hasil analisis aspek kognitif menunjukkan bahwa hanya 16 siswa atau $44,44 \%$ siswa yang mencapai ketuntasan dan 20 siswa atau 55,56\% siswa belum mencapai ketuntasan KKM yaitu dengan nilai 75 . Pada penilaian kognitif ini, terdapat 3 indikator yang harus dicapai siswa namun hanya 1 indikator yang melebihi target ketuntasan $70 \%$ yaitu menjelaskan pengertian isomer.

Penilaian siswa pada aspek afektif terbagi menjadi 4 kategori yaitu sangat baik (SB), baik (B), kurang baik (KB) dan tidak baik (TB). Hasil penilaian aspek afektif siklus I dapat dilihat pada Tabel 3. berikut.

Tabel 3. Hasil Penilaian Aspek Afektif Siklus I

\begin{tabular}{ccccc}
\hline \multirow{2}{*}{ Aspek } & \multicolumn{4}{c}{ Jumlah Siswa } \\
\cline { 2 - 5 } & SB & B & KB & TB \\
\hline Afektif & 7 & 19 & 10 & 0 \\
\hline
\end{tabular}

Dari analisis prestasi belajar aspek afektif yang dilakukan pada 36 siswa kelas X-2 SMA Negeri Kebakkramat, terdapat $19,44 \%$ siswa yang masuk dalam kategori sangat baik, 52,78\% siswa yang masuk dalam kategori baik, dan $27,78 \%$ siswa yang masuk dalam kategori kurang baik. Dengan demikian hasil aspek afektif siklus I sudah memenuhi target yaitu $70 \%$ siswa masuk dalam kategori sangat baik dan baik.

\section{d. Refleksi Tindakan}

Berdasarkan hasil diskusi denan guru dapat disimpulkan bahwa kurang berhasilnya pembelajaran pada siklus I disebabkan oleh beberapa faktor, diantaranya pada siklus I ini siswa belum terbiasa dengan model pembelajaran TAI, karena model pembelajaran ini baru pertama kali diterapkan oleh guru. Kemudian, walaupun kerjasama antar anggota dalam kelompok dan peran asisten yang cukup baik, masih ada beberapa siswa yang malu bertanya kepada guru mengenai materi yang mereka belum paham terutama pada materi menentukan isomer struktur pada senyawa hidrokarbon. Pada awal pembelajaran, guru sudah menyampaikan materi secara runtut, namun ada siswa yang mengeluhkan terlalu cepat dalam menjelaskan.

Berdasarkan hasil analisis siklus I menunjukkan bahwa kemampuan memori siswa belum tercapai. Namun masih akan dilakukan usaha dalam proses pembelajaran untuk meningkatkan kemampuan memori pada siklus II. Dari segi aspek kognitif siswa, masih belum mencapai target. Hal ini dikarenakan pada aspek kognitif siswa masih terdapat 2 indikator kompetensi yang belum dipahami siswa, yaitu menentukan isomer struktur (kerangka dan posisi) pada senyawa hidrokarbon dan menentukan isomer geometri (cistrans) pada senyawa hidrokarbon, sehingga masih perlu dilakukan perbaikan pembelajaran yaitu dengan melanjutkan ke tindakan siklus II. Penilaian afektif belajar siswa pada siklus I telah mencapai target yang diharapkan. Walaupun demikian, di akhir siklus II tetap diperlukan angket penilaian afektif untuk mengetahui bagaimana perkembangan respon siswa terhadap pelaksanaan proses pembelajaran.

\section{Siklus II}

\section{a. Perencanaan Tindakan}

Pelaksanaan pembelajaran pada siklus II hanya difokuskan pada materi dengan indikator-indikator yang belum tuntas pada siklus I yaitu 1). Menentukan isomer struktur (kerangka dan posisi) pada senyawa hidrokarbon, 2) Menentukan isomer geometri (cis-trans) pada senyawa hidrokarbon. Selain 
berfokus pada kemampuan pemahaman materi oleh siswa, guru juga mendorong siswa untuk lebih aktif lagi dalam proses pembelajaran. Untuk meningkatkan keaktifan siswa, guru menunjuk siswa yang masih belum aktif untuk mewakili kelompoknya dalam presentasi sehingga siswa menjadi lebih aktif.

\section{b. Pelaksanaan Tindakan}

Siklus II ini dilaksanakan dalam 2 kali pertemuan, yaitu 1 kali pertemuan untuk penyampaian materi dan 1 kali pertemuan untuk evaluasi siklus II. Seperti pada awal siklus I, pada siklus II ini guru memberikan apersepsi untuk mengingatkan kembali materi isomer struktur dan geometri pada pertemuan sebelumnya.

Pada kegiatan inti, guru melakukan sintaks model pembelajaran TAl seperti siklus I. Siswa dalam kelompok yang sama seperti pada siklus I, diminta untuk bertanya tentang hal apa saja dalam indikator kompetensi tersebut yang mereka rasa belum jelas. Siswa menanyakan tentang bagaimana menentukan isomer struktur, dan minta dijelaskan kembali mengenai isomer geometri. Dalam menerangkan guru lebih banyak menggunakan contohcontoh dalam aplikasi soal.

Siklus II menunjukkan bahwa banyak siswa yang lebih aktif dan bersemangat dalam mengikuti kegiatan pembelajaran. Siswa dalam kegiatan diskusi menjadi lebih aktif dan berkonsentrasi. Pada saat guru menawarkan adakah kelompok yang ingin mempresentasikan hasil diskusinya ke depan kelas, banyak siswa yang berebut untuk maju ke depan dan tidak hanya didominasi oleh asisten kelompok saja, namun anggota kelompok sudah berani untuk mempresentasikan jawaban di depan kelas.

\section{c. Observasi Tindakan}

Hasil Observasi keaktifan siswa sudah semakin meningkat. Hal ini dapat dilihat dari mulai banyaknya siswa yang aktif bertanya, berani menyampaikan pendapat dan berani menuliskan jawaban di papan tulis tanpa ditunjuk oleh guru. Siswa juga menjadi lebih aktif berdiskusi dalam kelompok dan saling bertanya tentang hal yang mereka belum pahami. Apabila belum begitu paham terhadap penjelasan asisten kelompok, siswa tidak malu menanyakannya pada guru.

Penilaian kemampuan memori siswa pada siklus II menggunakan metode yang sama halnya pada siklus I, namun berbeda daftar pasangan kata yang harus diingat oleh siswa. Hasil penilaian terhadap kemampuan memori siswa pada siklus II dinyatakan dalam Tabel 4.

Tabel 4. Hasil Penilaian Kemampuan Memori pada Siklus II

\begin{tabular}{cccc}
\hline \multirow{2}{*}{ Aspek } & \multicolumn{3}{c}{ Jumlah Siswa (Orang) } \\
\cline { 2 - 4 } & $\mathrm{T}$ & $\mathrm{S}$ & $\mathrm{R}$ \\
\hline $\begin{array}{l}\text { Kemampuan } \\
\text { Memori }\end{array}$ & 23 & 9 & 4 \\
\hline
\end{tabular}

Hasil analisis tes kemampuan memori menunjukkan bahwa pada akhir siklus II siswa dengan kategori kemampuan memori tinggi sebanyak 23 siswa atau $63,89 \%$, siswa yang masuk dalam kategori kemampuan memori sedang sebanyak 9 siswa atau $25,00 \%$, dan siswa yang masuk kategori kemampuan memori rendah sebanyak 4 siswa atau $11,11 \%$. Pada siklus II, penilaian kemampuan memori siswa sudah mencapai terget yang ditetapkan yaitu sebesar $60 \%$ siswa berkemampuan memori tinggi, sehingga untuk aspek kemampuan memori tidak perlu dilanjutkan ke siklus selanjutnya.

Hasil analisis aspek kognitif siklus II dapat dilihat pada Tabel 5.

Tabel 5. Hasil Tes Aspek Kognitif Siklus II

\begin{tabular}{lcc}
\hline \multirow{2}{*}{ Aspek } & \multicolumn{2}{c}{ Jumlah siswa } \\
\cline { 2 - 3 } & Tuntas & Belum Tuntas \\
\hline Kognitif & 27 & 9 \\
\hline
\end{tabular}

Hasil analisa aspek kognitif pada siklus II diperoleh bahwa sebanyak 27 siswa atau $75 \%$ telah mencapai ketuntasan KKM, sedangkan 9 siswa atau $25 \%$ belum mencapai ketuntasan KKM. Apabila dilihat dari ketuntasan tiap indikator menunjukkan bahwa semua 
indikator mengalami peningakatan pada siklus II. Target ketuntasan tiap indikator aspek kognitif sebesar $70 \%$.

Hasil penilaian aspek afektif siklus I dapat dilihat pada Tabel 6. berikut.

Tabel 6. Hasil Penilaian Aspek Afektif Siklus II

\begin{tabular}{ccccc}
\hline \multirow{2}{*}{ Aspek } & \multicolumn{4}{c}{ Jumlah Siswa } \\
\cline { 2 - 5 } & SB & B & KB & TB \\
\hline Afektif & 14 & 17 & 5 & 0 \\
\hline
\end{tabular}

Dari analisis prestasi belajar aspek afektif yang dilakukan pada 36 siswa kelas X-2 SMANegeri Kebakkramat, terdapat $27,78 \%$ siswa yang masuk dalam kategori sangat baik, 47,22\% siswa yang masuk dalam kategori baik, dan $13,89 \%$ siswa yang masuk dalam kategori kurang baik. Berdasarkan data tersebut, aspek afektif siswa mengalami peningkatan dibandingkan dengan hasil penilaian aspek afektif pada siklus I.

\section{d. Refleksi Tindakan}

Berdasarkan data yang diperoleh pada siklus II, terlihat semua aspek meliputi aspek kemampuan memori, kognitif dan afektif mengalami peningkatan capaian dan sudah melampaui target sehingga penelitian di akhiri pada siklus II.

\section{Perbandingan Tindakan Antar Siklus}

Berdasarkan hasil penelitian, kemampuan memori dan prestasi belajar siswa pada materi hidrokarbon mengalami peningkatan dari siklus I ke siklus II. Peningkatan tersebut dapat dilihat pada Gambar 1.

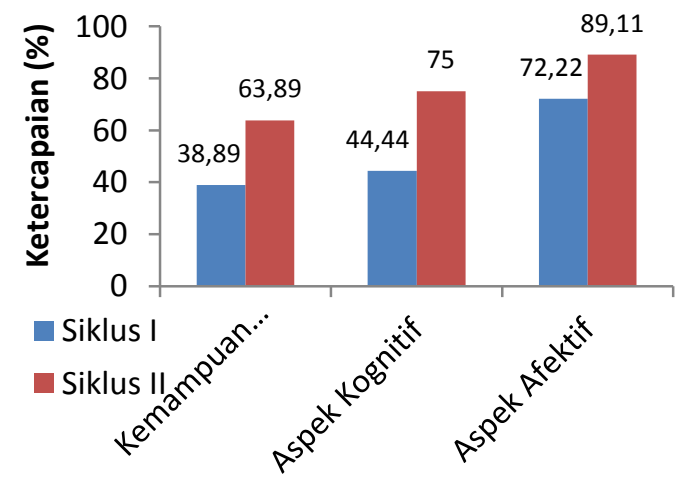

Gambar 1. Perbandingan Hasil Antar Siklus
Gambar 1 menunjukkan peningkatan dari siklus I ke siklus II pada aspek kemampuan memori, kognitif, dan afektif. Hal ini menunjukkan bahwa penggunaan model pembelajaran TAI dilengkapi dengan LKS berbasis drill and practice mampu meningkatkan kemampuan memori dan prestasi belajar siswa kelas X-2 SMA Negeri Kebakkramat pada materi hidrokarbon.

\section{KESIMPULAN}

Berdasarkan hasil penelitian yang telah dilakukan, maka dapat diambil kesimpulan bahwa penerapan model pembelajaran TAI dilengkapi dengan LKS berbasis drill and practice dapat meningkatkan kemampuan memori dan prestasi belajar siswa kelas X-2 SMA Negeri Kebakkramat pada materi hidrokarbon tahun pelajaran 2016/2017. Peningkatan kemampuan memori siswa pada materi hidrokarbon dapat dilihat dari kenaikan persentase siswa sebesar $38,89 \%$ pada siklus I dan meningkat menjadi 63,89\% pada siklus II. Prestasi belajar siswa pada materi hidrokarbon dapat dilihat pada aspek kognitif dan afektif. Berdasarkan hasil tes siklus I ketercapaian aspek kognitif sebesar $44,44 \%$ dan meningkat menjadi $75 \%$ pada siklus II. Ketercapaian aspek afektif siswa sebesar $72,22 \%$ pada siklus I dan meningkat menjadi $89,11 \%$ pada siklus II.

\section{UCAPAN TERIMAKASIH}

Penelitian ini tidak dapat berjalan lancar tanpa dukungan dari berbagai pihak, untuk itu penulis mengucapkan terimakasih kepada Drs. Bambang S. Maladi, MM selaku kepala sekolah SMA Negeri Kebakkramat yang telah memberikan izin untuk melakukan penelitian di sekolah tersebut. Terima kasih juga penulis ucapkan kepada Ida Lastari, S.Pd selaku guru mata pelajaran kimia yang telah ikut serta dalam pelaksanaan penelitian dan memberikan ijin peneliti untuk melakukan penelitian di dikelas X-2, serta kepada siswa-siswi kelas X-2 SMA Negeri Kebakkkramat tahun pelajaran 2016/2017 yang telah 
membantu penulis dalam menyelesaikan penelitian ini.

\section{DAFTAR RUJUKAN}

[1] Mulyasa, E. (2009). Standar Kompetensi dan Sertifikasi Guru. Bandung: PT. Remaja Rosdakarya.

[2] Ahmadi, L.K dan Amri, S. (2011). Paikem Gembrot Mengembangkan Pembelajaran Aktif, Inofatif, Kreatif, Efektif, Menyenangkan, Gembira, dan Berbobot). Jakarta: PT. Prestasi Pustaka Karya.

[3] Daryanto \& Rahardjo, M. (2012). Model Pembelajaran Inovatif. Malang: Gaya Media.

[4] Hijriyah, U.N. (2013). Keefektifan Model Pembelajaran Team Assisted Individualization terhadap Hasil Belajar PKn. Journal of Elementary Education, 2 (2).

[5] Widyantini. (2006). Model Pembelajaran Matematika dengan Pendekatan Kooperatif. Yogyakarta: Depdiknas.

[6] Arends, R.I. (2013). Learning to Teach. Yogyakarta: Pustaka Pelajar.

[7] Noor, Z, Mulyani, S. \& Masykuri, M. (2015). Penggunaan Model Pembelajaran Team Assisted Individualization (TAl) Dilengkapi Buku Saku dan Papan Karbon untuk Meningkatkan Kemampuan Memori dan Prestasi Belajar Siswa pada Materi Senyawa Hidrokarbon Kelas XI MIA Semester Gasal SMA Batik 1 Surakarta Tahun Pelajaran 2014/2015. JPK, 4 (2).

[8] Toman, U. (2013). Extended Worksheet Developed According to 5E Model Based on Constructivist Learning Approach. International Journal on New Trends in Education and Their Implications, 4 (4).
[9] Kusumah \& Dwitagama. (2012). Mengenal Penelitian Tindakan Kelas. Jakarta: PT Indeks.

[10] Sugiyono. (2012). Metode Penelitian Pendidikan: Pendekatan Kuantitatif, Kualitatif, dan $R \& D$. Bandung: Alfabeta.

[11] Anonim. (Tanpa Tahun). Instrumen Tes Kemampuan Memori. Yogyakarta: Departemen Psikometri Fakultas Psikologi Universitas Gadjah Mada.

[12] Walgito, B. (2004). Pengantar Psikologi Umum. Yogyakarta: Andi Offset.

[13] Sudjana, N. (2009). Penilaian Hasil Proses Belajar Mengajar. Bandung: PT. Remaja Rosdakarya. 